\title{
Potential Analysis of Building Child Friendly Regency in Accelerating the Implementation of the Convention on the Rights of the Child in Informal Education (Case Study in Nganjuk, East Java, Indonesia)
}

\author{
Zulkarnain \\ Faculty of Education, State University of Malang, Indonesia \\ zulkarnain.fip@um.ac.id
}

\begin{abstract}
Decent Regency Children is a term that was first introduced by the Ministry of Women's Empowerment in 2005 through the policy of District Eligible Children. The term of the Children's Eligible Regency becomes the City / District Worthy of the Child. Research Objectives: (1) analyzing the policy of the Nganjuk Regency government in establishing child-friendly districts; (2) analyze what support has been prepared and will be built by the government of Nganjuk Regency in the direction of the child-appropriate districts; and (3) analyze the implementation of the Convention on the Rights of the Child in establishing child-appropriate districts. This research uses qualitative research design case study with descriptive format. The conclusion is as follows: (1) to accelerate the realization of Nganjuk Regency into the development of Municipal Coverage, as the program priority in the field of welfare and child protection by establishing seven important aspects in KLA development: health, education, social, civil rights and participation, labor protection, and infrastructure. Based on data obtained from observations, interviews, and documentation of research results indicate that almost $85 \%$ Nganjuk District Government Apparatus has been preparing for the City of Children Worthy; and (2) implementation of the convention on the Rights of the Child in developing the Children Eligible Regency in order to realize the Nganjuk Regency to be the Children's Worthy Town is not an easy thing and is not a difficult thing. However, there is a kind of pre-requisite to achieve it. The prerequisite is the willingness and commitment of regional leaders, in accelerating the fulfillment of rights and child protection as reflected in the regional regulation document.
\end{abstract}

Keywords: child-friendly city, convention, children's rights

\section{INTRODUCTION}

Children are the next generation of ideals of freedom and sustainability of the nation and state. In addition, the child is the capital of development and the key to the advancement of the nation in the future. Children are proven to be able to make changes and solve problems more creatively, simply, and succinctly. As a form of efforts to fulfill the rights of children, the government must immediately realize the Children's Eligible District. Decent of Children District is the term that was first introduced by the Ministry of Women's Empowerment in 2005 through the policy of District Eligible Children. Due to the reasons to accommodate the district government, the term Children's Eligible District became the City / District Worthy of Children.

In the policy, it is illustrated that Kabupaten Eligible Regency is an effort of City / District government to accelerate the implementation of the Convention on the Rights of the Child (CRC) from the legal framework into definitions, strategies and development interventions such as child-friendly policies, institutions and programs. The normative juridical development of the Eligible District for Children is contained in the World Fit for Children, Presidential Decree No. 36/1990 on the Ratification of the Convention on the Rights of the Child, the 1945 Constitution on the Ratification of the Convention on the Rights of the Child, the 1945 Constitution (Article $28 \mathrm{~b}$ and $28 \mathrm{c}$ ).

The Children's Worthy Regency (KLA) is a city/regency development system that integrates the commitment and resources of the government, the business community and the planned, thoroughly and sustainably in policies, programs and activities for the fulfillment of children's rights (http://www.investor.co.uk/home/build-decent-child County, 15-05-2016). Therefore, protecting and making them a powerful generation is a necessity. However, the reality that occurred in Indonesia is far from expectations. That is, the Indonesian people still have not to say less-care about the development and future of children. This is evidenced by the many cases of exploitation, violence, and crime against children.

Based on the National Welfare Census Data (Susenas) in 2012, in Indonesia there are 1,502,600 children aged 10 to 14 who work and are not attending school, about 1,621,400 children are not in school and help at home or do other things. Susenas data also mentions the incidence of child labor and high school absence in rural areas. In 2004 there were an estimated 1.4 million children aged 10-14 working and earning a living. Most of them work long hours, they work in very dangerous areas and kill the future of children, which are called bad types of work. They also do not get educational opportunities that should be able to give them a better future.

This capital is then utilized by UNICEF to transform the Convention on the Rights of the Child from a legal framework, into a good formula of Child Friendly Movement nationally, covering families, communities, local and national governments, and the private sector. The movement aims to define and supervise community, schools, health facilities, workplaces, religious communities, and districts that deserve children. The idea of Decent Children District (KLA) begins with research on Children Perception of the Environment. The results show that the best district environments for children are those that have strong physical and social communities, communities that have clear and firm rules that provide opportunities for children, and educational facilities that allow children to learn about and understand the environment and the world they. 
Based on the background of the importance of research by raising the title Analysis in Building District Eligible Children Efforts Local Government District Ngajuk Acceleration Implementation Convention on the Rights of the Child in Informal Education. The purpose of this study are: (1) to analyze the policy of Malang Regency Government in Developing the Children's Eligible Regency; and (2) analyze what support has been prepared and will be built by the Government of Nganjuk Regency in Towards Child-Friendly District.

\section{METHODS}

This research uses qualitative research design. The researcher does an interpretation of the problem under study, since the main characteristics of qualitative are subjective-interpretative (Burhan, 2011). The type of qualitative research used case study with descriptive format. Case studies emphasize the cases that occur in the object of analysis. The case study in this study is a case study of the social community, where it sees the unique and meaningful sides of the surrounding social environment within the community in which it lives and interacts with society. Informants in this study related to the steps taken by researchers so that data or information can be obtained. Determination of informants to be studied conducted purposive procedures. Data collection techniques: (1) interviews; (2) observations; and (3) documentary or literary studies.

\section{RESULTS AND DISCUSSION}

To accelerate the establishment of Eligible Districts / Municipalities throughout Indonesia, the Ministry of Women Empowerment and Child Protection issues four State Ministries of Women Empowerment and Child Protection. The four rules are, first, the Regulation of the State Minister for Women Empowerment and Child Protection of the Republic of Indonesia Number 11 Year 2011 on the Development Policy of District/City of Children Eligible. Second, the Regulation of the Minister of Women's Empowerment and Child Protection of the Republic of Indonesia Number 12 Year 2011 on the Eligible District/City Indicators of Children. Third, the Regulation of the State Minister of Women Empowerment and Child Protection of the Republic of Indonesia Number 13 Year 2011 on the Development Guidance of District/City Decent of Children. Fourth, Ministerial Regulation of Women Empowerment and Child Protection of the Republic of Indonesia Number 14 Year 2011 concerning the Eligible District/City Evaluation Guide.

Indonesia has ratified the Convention on the Rights of the Child since 5 September 1990. This is Indonesia's commitment to respect and fulfill the rights of children. This commitment is contained in the 1945 Constitution of Article 28 B (2), and its operation in Law Number 23 Year 2002 on Child Protection. To transform the rights of children into the development process, the government developed the Municipal Decent City Policy. Districts that have a child-rights development system through the integration of commitments and resources of government, community and business, children (Children's Forum) are planned thoroughly and sustainably in policies, programs and activities to ensure the fulfillment of child rights and protection. Based on the results of observation shows Nganjuk District in implementing child-friendly districts as follows: (a) Strengthening the mandate of Law no. 35 of 2014 on Amendment to Law 23/2002 on Child Protection; (b) The Regional Government shall be responsible and responsible for implementing and supporting national policies in the implementation of child protection in the region (Article 21, paragraph 4); (c) The policy referred to in paragraph (4) shall be realized through the commitment of the region to build the Eligible District / City of Children (Article 21 paragraph 5).

Ngajuk District Policy in implementing Child Friendly City (Kota Layak Anak/KLA) based on instruction of Ministry of Women Empowerment and Child Protection in order to accelerate the fulfillment of rights and protection of children in Indonesia. Entering the seventh year of KLA development, there are more than 100 districts/ municipalities, especially the Nganjuk District Government which has committed to realize KLA. Various efforts have been made to strengthen the implementation of the KLA, so it is expected that children's rights can really be fulfilled, among others by advocating to local leaders, improving understanding of KLA indicators, and KLA evaluation and rewarding the regency/achieve KLA indicators with different categories. Another effort is to strengthen coordination between central and interdistrict/municipal governments through the KLA Technical Coordination Meeting.

The development of the KLA calls for the participation of governments consisting of legislative, judicial and executive from regional centers, child care NGOs, communities, businesses, and children themselves. All in synergy in filling the KLA in its territory of Ngajuk Regency. In each session in each sub-district, a deepening of indicators was conducted in order to develop the Regional Action Plan (RAD) of North Jakarta Municipality. The formation of Focus Discussion Group (FGD) based on kelurahan can practically map the problem of children in the neighborhood.

Based on the above indicator indicates that the District of Child Worth refers in the effort to fulfill the rights of the child. Indonesia has ratified the Convention on the Rights of the Child through Presidential Decree No. 36 of 1990, and to increase the Government's commitment to the fulfillment of children's rights, Law No. 23 of 2002 on Child Protection has been enacted. In addition, Government Regulation No. 38 of 2007 mandates that child development is one of the obligatory Provincial and District/Municipal Affairs.

This activity aims to increase the commitment of the Government and stakeholders in an effort to realize the District Nganjuk Worthy Children. In addition to integrating child protection policies through the formulation of strategies and district/city development planning as a whole and sustainable in 
education, health, social, infrastructure and environment, and child protection. Since compulsory health, education, including 'child protection' and others have been handed over by the central government to district and city governments, it has a great impact on the fulfillment of children's rights. Problems arise, such as the increasing of malnutrition cases, the decreasing of graduation rate in both primary and junior high schools and menengan or equivalent schools in some districts and cities.

Table 1

Based on the results of observation and interview of children eligible regency in general

\begin{tabular}{|c|c|c|c|c|c|}
\hline \multirow{2}{*}{ No } & \multirow{2}{*}{ Indicator } & \multicolumn{2}{|c|}{ Available } & \multirow{2}{*}{ Investigation } & \multirow{2}{*}{ Description } \\
\hline & & Yes & No & & \\
\hline 1 & $\begin{array}{l}\text { There are Rules for the fulfillment of } \\
\text { children's rights under the KLA }\end{array}$ & $\mathrm{X}$ & & $\begin{array}{l}\text { Social Service, Parks Department, } \\
\text { Nganjuk regency }\end{array}$ & $\begin{array}{l}\text { Law Number } 35 \text { Year } 2014 \text { on } \\
\text { Amendment to Law Number } 23 \text { Year } \\
2002 \text { regarding Child Protection }\end{array}$ \\
\hline 2 & $\begin{array}{l}\text { Availability of budget for child rights } \\
\text { fulfillment based on KLA }\end{array}$ & $\mathrm{X}$ & & $\begin{array}{l}\text { Social Service, Parks Department, } \\
\text { Nganjuk regency }\end{array}$ & \\
\hline 3 & $\begin{array}{l}\text { The existence of the Regency / City } \\
\text { Children's Forum }\end{array}$ & $\mathrm{X}$ & & Focus Discussion Group (FGD) & Implemented 1 (one) month \\
\hline 4 & $\begin{array}{l}\text { All personnel / service providers to } \\
\text { KLA trained children }\end{array}$ & $\mathrm{X}$ & & $\begin{array}{l}\text { Social Service, Parks Department, } \\
\text { Nganjuk regency, } \\
\text { community of children, PAUD }\end{array}$ & \\
\hline 5 & $\begin{array}{l}\text { The availability of child data is } \\
\text { disaggregated by sex, age, and district }\end{array}$ & $\mathrm{X}$ & & & $\begin{array}{l}\text { In the process of completing the } \\
\text { preparation }\end{array}$ \\
\hline 6 & $\begin{array}{l}\text { Availability of service providers for } \\
\text { growth and protection of children and } \\
\text { adolescents based on community }\end{array}$ & $\mathrm{X}$ & & $\begin{array}{l}\text { Nongovernmental organization, } \\
\text { Social Service, Parks Department, } \\
\text { Nganjuk regency }\end{array}$ & \\
\hline 7 & $\begin{array}{l}\text { Involvement of the business world in } \\
\text { efforts to grow and protect children }\end{array}$ & $\mathrm{X}$ & & $\begin{array}{l}\text { State Owned Enterprises (BUMN), } \\
\text { corporations }\end{array}$ & $\begin{array}{l}\text { Program Corporete Social } \\
\text { Responsibility (CSR) }\end{array}$ \\
\hline
\end{tabular}

But from a series of issues that plague the child, the real thing that needs to be understood by us is the acceptance of various international commitments agreed by the State for the advancement of Indonesian children. Based on the data obtained from observations, interviews, and documentation of research results indicate that almost $85 \%$ of Nganjuk District Government Apparatus has been preparing to Kota Layak Anak (KLA), the future of 2016 Nganjuk has also been preparing a play unit for children in parklands or a renovated field into a beautiful garden and children's playground.

When traced, the implementation of children and cities has been going on since the 1970s until now. The results of the observation indicate that the best urban environment for children is that having: a strong community physically and socially, a community that has clear and decisive rules; the existence of giving opportunities to children; and educational facilities that allow children to learn and explore their environment and world.

From these observations, it is very interesting that children, like adults, can be co-opted and address issues related to the city's environment (Adams \& Ingham, 1998). Governments can consult with them, as they have perceptions, views and experiences about the city environment in which they live. Of them, the government and stakeholders in the field of children can find their need or aspiration to accelerate the implementation of the Convention on the Rights of the Child and other State commitments in the field of children. Children can assist the government in obtaining data on neighborhoods, neighborhoods, school environments, playgrounds, transport services and health services. The child will have an invaluable experience of their involvement.

Eighteen years ago, Indonesia committed to ensuring that every child is given a better future with the ratification of the Convention on the Rights of the
Child. Since then great progress has been made, as stated in the Government of Indonesia's report on the implementation of the Convention on the Rights of the Child to the Committee on the Rights of the Child, Geneva, more children are in school than in the past, more children are becoming actively involved in decisions about their lives, important legislation that protects the child. This condition becomes an important point in accelerating the formation of KLA.

However, these outcomes are uneven, and obstacles still exist, especially in the few districts and cities left behind. The bright future for the child is only a 'fantasy', and that achievement generally does not meet the government's obligations and state commitment. The family as the basic unit of the society that determines the success in accelerating the realization of state commitment has not received assistance and guidance regularly, organized, and scheduled. The primary responsibility for protecting, educating and developing children lies with the family. However, all government agencies and communities have not helped much. It should respect the rights of children and ensure the well-being of children and provide appropriate assistance and guidance to parents, families, caregivers, and parenting parties in order to grow and thrive in a safe and stable environment and a happy, loving and understanding. In addition, there are different understandings among parents about the meaning of the child. In some parents understand children as 'amanah' and 'deposit' that must be protected and appreciated. While in some parents 'children' as 'family assets' and 'children must understand parents'. This latter understanding is sometimes the child victim of child trafficking, economic and sexual exploitation, and growing and growing neglected.

A large number of children live without the help of parents, such as orphans, street children, refugee children, and children displaced from their homes, 
child victims of trafficking, child victims of economic and sexual exploitation, and those in prisons, special attention and protection. The same thing is also experienced by social institutions that provide services to these children lack of coaching and appreciation from the government and society. Another fairly basic issue is poverty which is the single biggest obstacle that hinders efforts to meet the needs, protect and respect the rights of children. It should get attention and support from the government and society. However, efforts to address these issues in various districts and cities have not been well planned from job creation, micro-credit availability to infrastructure investment. Children are the people who are hardest hit by poverty, because the poverty is very scattering them to grow and develop.

One of the paradoxes of modern human development is the recognition of children as the future of humanity, but at the same time as the most vulnerable population group because it is often ignored and sacrificed in the process of development itself. As the economy improves and development in all areas is excited, the child's interests are not a priority. However, when the economy worsens, conflicts rage, social chaos develops everywhere, children become victims or made sacrifices to meet the needs of adults. Of the unique problems above are the regional autonomy. Since compulsory health, education, including 'child protection' and others have been handed over by the central government to district and city governments, it has a great impact on the fulfillment of children's rights. Problems arise, such as the increasing of malnutrition cases, the decreasing of graduation rate in both primary and junior high school or senior high school or equivalent in some districts and cities.

But from a series of issues that plague the child, the real thing that needs to be understood by us is the acceptance of various international commitments agreed by the State for the advancement of Indonesian children. Call it the World Declaration and Action Plan of the World Summit for Children, The Dakar Framework: Education For All of the World Education Forum, the Millennium Development Goals Declaration and the World Fit for Children Declaration and Action Plan, and the last Declaration and Sustainable Development Plan of the World Summit on Sustainable Development. All the arrangements are stored neatly in the cabinets and drawers of the Indonesian Delegation that they actually also have limitations in terms of science, mastery of children's issues to communication. The documents have not been socialized to the government, local government, community, family, parents, and children. This has created an information gap between stakeholders and international planners and program developers in the field, as all of these international agreements have not become references in development program planning and policies. It is only natural that we find different understandings among parents, families, communities, and district or city governments to "fulfill children's rights" in accordance with the Convention and the State's commitment. Because they basically do not know and understand what really has become the commitment of the State at world level.

The mass media has not taken a proportional role. Children's issues are always losing out in 'plotting' or space in the mass media, print and electronics, and in no way competing with political issues that dominate media proclamation. The logical consequence is that public opinion and understanding of children's issues lags far behind what they should be. When met with media that raised the issue of children in the segment of the event or portion of the news impression that arise precisely the potential abuse of children's rights. Because placing the child as the object of the program so that it is very much encountered news and programs in the mass media that actually keep children from the originality of culture and even make the children of Indonesia contaminated by foreign culture. From the description above, it is illustrated that there are major challenges to accelerate the implementation of children's rights at the parent, community, district / city, provincial and national levels in the present and the future. Though the problem is not only the child, however, if we do not immediately berinisatif, feared best interests for children neglected. That is, their right to grow and develop less than optimal, which will lead to the loss of a generation of the nation.

Implementation of the Convention on the Rights of the Child Establishes Children's Eligible District. Here are some of the expectations and needs of children they conveyed well recorded in research reports. In the community environment, it is expected that children can better adjust to the community environment, it is necessary to consider that: To make the community environment as a good place for children to grow and flower, the city government needs to make improvements. According to Bartlett, children understand what their needs are in their environment. Children recommend and prioritize important things that need attention from adults, community associations and city government. To improve their society. There needs to be repair, maintenance and renovation of drains, toilets that do not smell, smellfree of garbage; safe and complete playground and recreation, with children determining suitable locations for playgrounds close to home and school; and need to take extra security in low-income environments, and post announcements on child protection from violence and neglect of children.

Children and School Environments, the school environments that children expect are as follows: (1) having a WC room is one of the important facilities in the school, so it needs to be considered its existence and needs, children object if the girls and boys WC rooms are put together; (2) the design of multi-storey school buildings should be equipped with a playroom that allows children from every floor to meet and consolidate each other; (3) school and morning time are considered to be applied interchangeably, because it is very influential on teaching and learning process and quality of pupils, most of the early evening school students are less than optimal for lessons, due to reduced energy and hot air affecting children's absorption of learning; (4) teaching 
methods are not just classical methods, so children are trained to discuss a problem, methods of active student learning or other methods that give children opportunities for discussion, need to be applied so that trained children express their opinions or ideas; and (5) formulation of school rules and regulations, school leaders and teachers need to include students, so they have strong legitimacy when applied and enforced.

This activity trains children about the democratic life that listens to each other, and values the opinions of others. The child has the potential to develop rules and regulations concerning his own life; For example, through play they formulate agreed and joint rules, and if there are any violators, there is obvious sanction. Another example is the division of cleaning duty tasks that they set up together with the classroom leader, run together in school to be considered into a school program, because many benefits can be obtained from this activity, in addition to restoring the energy of children who are used during learning, improve the nutrition of children, who may be at home lack of nutritious food intake. In addition to being a good place to socialize children with other classmates or other classes.

Children and the Environment Playing, the government needs to learn how children fulfill their desire to get play by following the children's way, and willing to work with them to organize the space. The consultation process with children should be done well as it does with adults. An important topic that planners and designers need to address when discussing with children about building a playground is a child safety issue.

There are two issues related to child safety: (1) necessary precautions and experienced professionals are required to ensure that the room is free from harmful things that can cause children to be seriously injured; and (2) adults, especially parents of children and supervisors of playgrounds are suspected of having the potential to endanger the safety of children and make children afraid. This issue involves cases of violence against children. In addition, planners and designers need to consider child protection and supervision. The city authorities need to consider security and supervision on the playground; improve child safety at the playground; and includes conducting campaigns against the prohibition of the use of hazardous substances on game equipment.

One of the playground for children that has been built by the Government of Nganjuk Regency and now under construction is Nganjuk, Bangsaonline. Finding a place to play for a holiday does not always have to spend our pockets, or have to travel far out of town.Such as Nganjuk people for example, which will soon have a means of playing for children and parents centered in the heart of the city Nganjuk, to be exact Alun-Alun (the Squere) Nganjuk, as a place of Green Open Space. Currently Nganjuk square is starting work that will be functioned as a means of play for children who fill the school holidays and sports time off on Sunday.

The park offers a variety of supporting facilities ranging from sports, children's play facilities, jogging tracks, fountains, reading parks and more. The view presented was enough to spoil the eyes with cool air from the wind breeze trees that look green. The park is divided into two main functions, namely the sport on the north side includes two futsal courts and one basketball court. In addition, the existence of this park is also much welcomed, especially the komonitas sports lovers cycling BMX, Skateboarding, and other challenging sports. This park will also be able to just sit around while looking for inspiration. There are many iron benches provided in the garden area with a capacity of three people.

Child and Transportation Services, the municipal government to provide transportation services that consider the needs of children. To realize such transportation, the government can study and study the transportation system in Singapore that provides services to a wide range of population situations, or assess the transportation system in Curitiba, Brazil. Assessing and adopting two examples of transport systems and consulting with city residents including children on transport needs, it is conceivable that districts in Indonesia will have a proper transportation system for children.

In addition, it needs to be considered to channel the school community to build a 'Safe Route to School'. This idea has actually been developed in several districts and cities in Indonesia through the School Safe Zone Program by the Department of Transportation, but it is unfortunate that this program is not consulted with children, so the program has not received a serious response from parents and the community, and impressed the program was forced.

Child and Health Services, Information on children's health is something that a child needs to know, so that they know the source of the disease, the type of disease and its prevention efforts. Child's life is centered on home, school and the surrounding environment. Therefore, the area should be a safe and healthy place for children. In fact, not infrequently these places are not safe even be a cause of disease for children. According to WHO (2002), most childhood illnesses are closely related to the environment in which they live (home), learning (schooling) and playing (community). Major risks are caused by the environment such as clean water, poor sanitation, air pollution, and poor food hygiene. For urban communities, risks also arise from lack of care in the use of hazardous chemicals, toxic waste disposal and environmental degradation. The use of unsafe chemicals for household products and children's play tools such as dolls, can also be a threat.

Other measures that governments may undertake are providing supervision, protection of children and taking action on the water, sanitation, waterways, schools, housing, parks, public transport, waste management sectors as well as considering responsibilities for children: (1) institutions are responsible for pollution regulations that can damage the development of the child's brain and body; (2) the government is responsible for road conditions that may cause accidents and injuries; (3) regulations on water and sanitation that can be a source of diarrheal diseases 
and worm infections; and (4) police arrange parks and other public places visited by many children.

Realizing the District of Nganjuk Worthy Children is a District that guarantees the rights of every child as a citizen of the city. As a citizen, the child means: (1) his decision affects his city; (2) be able to express their opinions about the city they want; (3) may participate in family, community, and social life; (4) be able to access basic services such as health and education; (5) be able to access fresh drinking water and live in an environment with good sanitation; (6) protected from exploitation, violence and neglect; (7) feel safe walking down the street; (8) can meet and play with his friends; (9) living in a pollution-free environment; (10) participate in cultural and social activities; and (11) can equally access any service, regardless of ethnicity, religion, property, gender, and disability.

The treatment of the playing environment, the learning environment, and the public facilities provided by the government, such as roads, transportation, recreation, and others are also not suitable for children (Pudjijulianingsih, 2009). This fact shows us that the child's problems are extraordinary despite the regulations that protect them. The 1945 Constitution, for example, clearly regulates the rights of the child, as set forth in article 28B paragraph 2, every child shall have the right to survive, to grow and to develop and to be entitled to protection from violence and discrimination.

Law Number 23 Year 2006 concerning Population Administration; and Law 17/2007 concerning the National Long-Term Development Plan (RPJPN) 2005-2025 which includes government efforts to improve the welfare of children and realize healthy, smart, cheerful and noble Indonesian children; and protect children against various forms of violence, exploitation, and discrimination. Then, the State Ministry of Women Empowerment (KPP) with the sector related government organizations, civil society organizations and non-governmental organizations to develop the model of Decent City Children, the city in which has concocted the spirit to provide protection for children as an activity or efforts to guarantee and protect children and their rights in the process of sustainable development as outlined in Ministerial Regulation The State of Women Empowerment RI Number 2 Year 2009 on the Policy of the City / Kabupaten Eligible Children (KLA). The KLA is intended as a concrete effort to unite the issue of child rights into district planning and development (KLA Guidelines, 2006). Following up on the national policy, each local government adopted a Policy aimed at protecting child rights tailored to the needs of the region and the conditions of its regional autonomy.

Departing from various problems that occur in Nganjuk District, then formulated the policy of decent city/district children by the Ministry of Women Empowerment No. 2 Year 2009 which was then adopted by Nganjuk regency to become the Children's Eligible District (K3LA) since 2009. As far as the indicators are reached, so far as a district / city can be said worthy of children. Establishment of the K3LA
Task Force through the Bupati's Decree. After the formation of a task force, several steps have been taken by the task force, among others: "Semiloka Towards Nganjuk District Worthy Children", and then need to do coordination meeting.

Stages And Approach Development Nganjuk District Decent Son Development Nganjuk District Eligible Children, Includes Four Stage: yaknik (1) formation of task force; (2) determination of program focus and RAD; (3) local action plan and base line data, and (4) resource mobilization approach: Nganjuk District of Child-Friendly is developed from, regency and ends in decent families and vice versa decent families child village / children of regency / city worthy of children.

Children can assist the government in obtaining data on neighborhoods, neighborhoods, school environments, playgrounds, transport services and health services. The child will have an invaluable experience of their involvement. Through this engagement activity the child becomes thinking about his environmental problems, and can identify the problems that are to be discussed and solved together. They can also contribute to the city planning and development process they expect (Adams \& Ingham, 1998). From these observations, it is very interesting that children, like adults, can be co-opted and address issues related to urban environments (Adams \& Ingham, 1998).

The initiative and willingness of the RT and RW heads to run the organization by establishing activities that directly impact the citizens, especially children, such as the work of devotion (cleaning garbage and sewerage), and siskamling. Without such initiative and will, the townspeople, according to Prof. Parsudi Suparlan (Suparlan, 1996: 3-44) becomes characterized by high individualism. The government needs to learn how children fulfill their desire to get a playground by following the children's way, and are willing to work with them to organize the space.

Nganjuk District Children's Forum has been formed since July 27, 2011 and until now has produced 19 work programs that have been implemented. Activities for the success of the work program that has been announced is to conduct socialization at schools at the elementary, junior and senior high schools on the rights of children. In addition, the activities of children's forums also conduct activities ngungkuk children meeting activities initiated by this child's forum as a medium of socialization and discussion for children i nganjuk district. Currently, there are 75 representative children from all levels of education and areas in Nganjuk district. The existence of the forum of children is very important, this is because as a container to provide education, the fulfillment of children's rights, and as the successor of development in the future. The existence of a children's forum will also help regional development, as the child is a future investment and asset for a better nation change.

Nganjuk District Children's Forum also conducts social activities in all areas in Nganjuk regency. The form of social activities that are carried out varies, ranging from extension activities on 
children's rights, anticipating the abuse of children, and performance activities aimed at exploring the potential and creativity of children from all walks of life. Even activities such as they do start from planning, extracting funds, and executing activities. Obviously with the existence of this child forum will have a positive impact on the development of children as well as avoid children from negative activities that occur in children

The existence of the children's forum in Nganjuk District also received support from the local government. This is evidenced by the existence of local regulations that protect the rights of children. In addition to the regional development planning meetings, the local government also involves and invites representatives of children's forums to participate in regional development planning.

\section{CONCLUSION}

To accelerate the realization of Nganjuk Regency into the development of Decent City Children (KLA), as program priority in the field of welfare and child protection by establishing 7 (seven) important aspects in KLA development are: (1) health; (2) education; (3) social; (4) civil rights and participation; (5) legal protection; (6) employment protection; and (7) infrastructure. Based on the data obtained from observations, interviews, and documentation of research results indicate that almost $85 \%$ of Nganjuk District Government Officials have been preparing for the City of Children Worthy (KLA), the future of 2016 Nganjuk has also prepared satan play for children in the parklands or a renovated field into a beautiful garden and children's playground.

Support that has been prepared and will be built by the Government of Nganjuk Regency Toward a Children's Worthy District include: (1) children and school environment; (2) children and the environment of play, in this case Pemkab Kabupten Nganjuk need to learn how children fulfill their desire to get a playground by following the child's way, and willing to cooperate with them to arrange the existing space, such as children's playgrounds; (3) child and transportation services, in this case Nganjuk Regency Government to provide transportation services that consider the needs of children, by studying and adopting two examples of transport systems and consulting with city residents including children on transport needs, it is conceivable that districts in Indonesia will have a proper transportation system for children; (4) child and health services. Information about children's health is something that a child needs to know, so that they know the source of the disease, the type of disease and its prevention efforts. Child's life is centered on home, school and the surrounding environment; and (5) police organize parks and other public places visited by many children.

Implementation of the Convention on the Rights of the Child (CRC) in developing the Eligible District for Children. in order to realize the Nganjuk Regency to be the City Worthy Children (KLA) is not easy and is not a difficult thing. However, there is a kind of prerequisite to achieve it. The preconditions are: (1) the willingness and commitment of regional leaders, in accelerating the fulfillment of child rights and protections as reflected in the regional regulatory documents; (2) baseline data, available data and basic data systems used for planning, programming, monitoring and evaluation; (3) the socialization of the rights of the child, ensuring the awareness of the rights of children to children and adults; (4) decent legal products of children, the preparation of laws and regulations to promote and protect the rights of children; (5) child participation: a forum for promoting activities involving children in programs that will affect them, hear their opinions and consider them in the decision-making process; (6) family empowerment, a program to strengthen family capacity in care and child care; (7) partnerships and networks: the existence of partnerships and networks in the fulfillment of children's rights and protections; and (8) Child Protection Institutions: An institution that coordinates all efforts to fulfill the rights of the child.

There are still many employees who still do not understand the concept of KLA and PUHA, therefore need an intensive and coordinated socialization to employees about the concept of Decent City Children. To accelerate the realization of the development of Decent City Children (KLA), in Nganjuk district make this KLA model as program priority in the field of welfare and child protection by establishing 7 (seven) important aspects in KLA development: health, education, social, civil rights and participation, legal protection, employment protection, and infrastructure. The government needs to learn how the child fulfills his desire to get a playground by following the child's way to organize the space. Planning a fair playground for children should consider the outcome of consultation with educational experts, and child psychology as well as learn about the characteristics of the child themselves as how they use space and what they want to do, so that in the development process there is no need to exercise restraint on children. Thus it can realize the Implementation of the Convention on the Rights of the Child (CRC) in building the District of Nganjuk Worthy Children.

\section{REFERENCES}

[1] Adams, E., \& Ingham, S. 1998. Changing Places: Children's Participation in Environmental Planning. London: The Children's Society.

[2] Suparlan, P. 1996. Urban Anthropology. Depok: Departement Anthropology, Indonesia University.

[3] Peraturan Menteri Negara Pemberdayaan Perempuan dan Perlindungan Anak Republik Indonesia Nomor 11 Tahun 2011 tentang Kebijakan Pengembangan Kabupaten/Kota Layak Anak. 2012. Bandung: Citra Umbara.

[4] Peraturan Menteri Negara Pemberdayaan Perempuan dan Perlindungan Anak Republik Indonesia Nomor 12 Tahun 2011 tentang Indikator Kabupaten/Kota Layak Anak. 2012. Bandung: Citra Umbara.

[5] Peraturan Menteri Negara Pemberdayaan Perempuan dan Perlindungan Anak Republik Indonesia Nomor 13 Tahun 2011 tentang Panduan Pengembangan Kabupaten/Kota Layak Anak. 2012. Bandung: Citra Umbara. 
[6] Peraturan Menteri Negara Pemberdayaan Perempuan dan Perlindungan Anak Republik Indonesia Nomor 14 Tahun 2011 tentang Panduan Evaluasi Kabupaten/Kota Layak Anak. 2012. Bandung: Citra Umbara.

[7] Peraturan Pemerintah Nomor 38 Tahun 2007 tentang Pemerintah Provinsi dan Kabupaten/Kota Pembangunan Anak. 2012. Bandung: Citra Umbara.

[8] Undang-undang Nomor 17 Tahun 2007 tentang Rencana pembangunan Jangka Panjang Nasional (RPJPN) 2005-2025 Kesejahteraan Anak Indonesia. 2008. Bandung: Citra Umbara. 